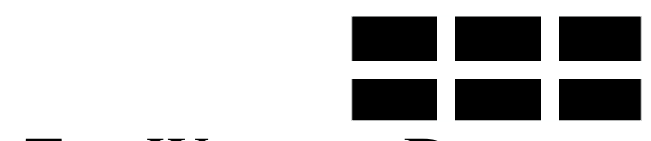

THE WILLIAM DAVIDSON INSTITUTE AT THE UNIVERSITY OF MICHIGAN BUSINESS SCHOOL

\title{
PRIVATE SAVINGS IN TRANSITION ECONOMIES: ARE THERE TERMS OF TRADE SHOCKS?
}

\author{
By: Abdur R. Chowdhury
}

William Davidson Institute Working Paper Number 572

May 2003 
PRIVATE SAVINGS IN TRANSITION ECONOMIES:

ARE THERE TERMS OF TRADE SHOCKS?

\author{
Abdur R. Chowdhury \\ Professor of Economics \\ Marquette University \\ Milwaukee, WI 53201 \\ abdur.chowdhury@marquette.edu \\ and \\ Senior Researcher \\ Institute for Economies in Transition \\ Bank of Finland \\ P.O. Box 160 \\ Helsinki 00101, Finland \\ abdur.chowdhury@bof.fi
}

I would like to thank Tuomous Komulainen, Iikka Korhonen, Jouko Rautava, Pekka Sutela and seminar participants at the Bank of Finland, Estonian-Finnish Joint Seminar on Economic Integration and the EU Enlargement, Tallinn, November 2002 and the CEPR-William Davidson Institute Annual International Conference on Transition Economics, Budapest, 2003 for helpful comments. 


\section{PRIVATE SAVINGS IN TRANSITION ECONOMIES: ARE THERE TERMS OF TRADE SHOCKS?}

Abstract:

The paper examines the impact of terms of trade shocks on private savings in the transition economies after accounting for the effect of other determinants. Economic agents in the transition economies are subject to tight credit constraints which are more pronounced during bad state of nature. Thus, adverse shocks to commodity prices in the world market can force them to reduce savings by a larger amount than they would otherwise have. Empirical analysis using a dynamic panel model and data from twenty one transition economies confirm that most of the determinants of savings identified in the literature also apply to the transition economies. Favorable movements in both the permanent and transitory components of the terms of trade have a significant positive impact on private savings with transitory movements having a larger impact than the permanent component. This reflects the lack of access to foreign borrowing that many of the transition economies have faced during the last decade. Although the impact of terms of trade shocks are found to be asymmetric, the magnitude of the impact appears to be small. The results are robust for alternative estimators, determinants, and country groupings.

JEL classification: F10, E21, P33

Key words: transition, private savings, terms of trade 


\section{Introduction}

Savings in the transition economies of Central and Eastern Europe and Central Asia involved the shift from centralized investment to decentralized savings as the economic system moved from central planning to market principles. The absence of efficient domestic credit and capital markets and limited access to international financial markets due to specific macroeconomic and institutional risks have made private savings a key determinant of welfare in these economies. Without savings, households have few mechanisms to smooth unexpected changes in their income. ${ }^{1}$ In fact, the capacity to save is crucial for increasing social mobility and raising future income-earning possibilities. In the early years of transition, most of these economies have witnessed a sharp decline in domestic savings rate [EBRD (1996)]. A striking feature of this decline has been the dramatic shift in the composition of savings towards households and away from corporate and general government. Because of the growing importance of households in wealth accumulation in transition economies, the absence of much empirical research on the actual pervasiveness of their resource constraints, and of the extent to which such constraints may be reducing their growth prospects, it is both timely and essential to study the role of various factors that affect private savings.

While a number of studies including Borensztein and Montiel (1991), Conway (1995, 2000), and Denizer and Wolf (2000) have tried to examine the behavior of aggregate savings in the transition economies, there has been very few attempts to study the determinants of private savings. ${ }^{2}$ This paper attempts to fill the gap in the literature by analyzing the motives behind private savings to see if it is driven by the same forces as in a market economy. In this

\footnotetext{
${ }^{1}$ The sharp rise in income uncertainty and changes in expectation of future income profiles can be attributed to the move from a system of state-guaranteed incomes to market determined wages, increase in unemployment rate and decrease in public benefits [see Denizer et al (2002) on this issue].

${ }^{2}$ Exceptions include Denizer et al (2002), IMF (2000a) and Schrooten and Stephan (2002) on a number of East European and EU-Accession countries.
} 


\section{William Davidson Institute Working Paper 572}

context, the paper will specifically analyze the impact of terms of trade shocks on private savings after controlling for other determinants.

There has been a voluminous literature on the potential importance of terms of trade shocks in explaining macroeconomic performance. ${ }^{3}$ A question regularly raised in these studies is: how should economic agents respond to greater fluctuations in tradable commodity prices, and the resulting volatility in current account balances and real income? One answer, provided by the theory of precautionary savings, suggests that in response to an increase in the volatility of income arising, say, out of an increase in the probability of being unemployed, economic agents would increase savings in order to hedge against the greater problem of a large negative income shock in the future. The international economics literature beginning with studies by Obstfeld (1982), Sachs (1981), and Svensson and Razin (1983) have devoted particular attention to the response of private savings to terms of trade shocks in the context of macroeconomic models where spending decisions are based on intertemporal optimization by forward-looking agents. An important result emerging from this work is that the nature of the impact of these shocks on private savings depend on whether the shocks are permanent or transitory, and expected or unexpected.

Why is this an important issue for the transition economies? Terms of trade disturbances have been an important source of macroeconomic uncertainty in a number of these countries [World Bank (1999)]. ${ }^{4}$ Many of them remain heavily dependent on primary commodities increasing their vulnerability to external shocks, and complicating macroeconomic management, particularly on the fiscal side [see Table 1a; and United Nations (2002), pp. 139-46]. For instance, primary commodities dominate the exports of many of the former

\footnotetext{
${ }^{3}$ For an early work in this area, see Bevan et al (1993). Using cross-country growth regressions, Barro and Salai-Martin (1995) have shown that a change in the growth rate of terms of trade by 3.6 percentage points leads to a 0.4 percentage point change in the growth rate of real per capita GDP. Mendoza (1997) and Agenor et al (2000) also found terms of trade disturbances to be highly correlated with output fluctuations.
} 
Soviet Union (FSU) countries. Azarbaijan, Kazakhstan and Russia depend significantly on

foreign sales of crude oil, natural gas and oil products. Exports of base and ferrous metals are important to Kazakhstan, Russia, Tajikistan and Ukraine; while cotton and gold sales are important for the exports of Central Asia [IMF (2000b)].

Recent events associated with, on one hand, the sharp decline in commodity prices in the 1990 s, and, on the other, the continuous increase in the volatility of commodity prices over the past two decades have exacerbated the pressure on the current account of these countries (see Table 1b). ${ }^{5}$ For example, since 1998 the rebound in world oil price have helped to boost the Russian economy; while many of the non-oil producing countries in Central Asia have faced substantial terms of trade losses as export prices of non-fuel commodities and other primary products remain generally depressed, particularly in real terms, while energy import prices have risen. Moreover, commodity price changes also tend to be asymmetric often with long troughs and sharp peaks, making it difficult to insulate the domestic economy from such shocks [Cashin et al (2002), Spatafora and Warner (1999)]. ${ }^{6}$

Given the absence of efficient domestic credit and capital markets and limited access to international financial markets, economic agents in the transition economies are subject to tight credit constraints which are more pronounced during bad state of nature. Consequently, adverse shocks to commodity prices in the world market can force them to reduce savings by

\footnotetext{
${ }^{4}$ Several studies have emphasized the importance of trade dynamics in the process of transition [see Campos and Coricelli (2002) and the references therein].

${ }^{5}$ Reinhart and Wickham (1994) show that commodity prices have experienced a mostly secular decline accompanied by an increase in volatility. The standard deviation for terms of trade growth has ranged from an average of 9 percent per year for developed countries to about 19 percent per year for developing countries [Baxter and Kouparitsas (2000)]. The World Bank's index of non-oil real commodity prices have also shown a trend decline of about 1.5 percent per annum since the late 1940s. The Bank predicts this trend to continue over the next decade.

${ }^{6}$ Cashin et al (2002) found commodity price cycles to be asymmetric - price slumps last longer than price booms. Averaging across 36 real commodity price series, they estimated the typical length of price slumps (39 months) to be about 10 months longer than the typical length of price booms, giving an average cycle of about 68 months. Using a stock-holding model with intertemporal arbitrage, Deaton and Laroque (1992) identified the asymmetry involved in storage activity - stocks cannot be negative and a stock-out will lead to sharp price fluctuations - as the reason for this pattern of commodity price movements.
} 


\section{William Davidson Institute Working Paper 572}

a larger amount than they would otherwise have. Empirical studies on the impact of terms of trade shocks on private savings have almost unanimously excluded the transition economies on the ground that their performance is less amenable to explanation using standard economic variables. This is one of the first studies that we are aware of that tackles this issue for the transition countries with the realistic expectation of obtaining results comparable in quality and reliability to those available in the literature.

Empirical work on the transition economies suffer from at least two drawbacks. First, the transition constitutes a structural change in the way the economy is organized. Second, the available sample period after transition is very short. As a result, many of the studies on the transition economies have opted for panel approach as it exploits the time-series dimension of the data instead of using only cross-sectional estimators. This paper uses the newly developed GMM dynamic panel data procedure that controls for bias arising out of the presence of simultaneity, use of lagged dependent variable, and omission of country-specific effects [Edison et al (2002)] . This, however, gives rise to a number of potential problems as discussed in the literature [See, Campos and Kinoshita (2002)]. The basic results in the paper are, therefore, subjected to a number of sensitivity tests to check the robustness vis-a-vis alternative estimators, determinants, and country groupings.

The paper is organized as follows. Section II reviews the literature; while the methodology is discussed in Section III. Section IV introduces the savings function. Empirical results and sensitivity test analyses are presented and discussed in Section V. The paper ends with concluding remarks in Section VI.

\section{Literature Review}

What is the impact of movements in the external terms of trade on private savings? This question has been a source of a major debate in international economics for the last few 


\section{William Davidson Institute Working Paper 572}

decades. $^{7}$ The traditional explanation, known as the Harberger-Laursen-Metzler (HLM) effect [Harberger (1950), Laursen and Metzler (1950)], states that an improvement in the terms of trade increases a country's real income level (that is, raises the purchasing power of its exports in the world market). In a single-good static Keynesian open-economy model, assuming the marginal propensity to consume to be less than unity, private savings will increase. Using similar arguments, a deterioration in the terms of trade can be shown to lower private savings.

In later years, the literature moved in two different directions. The Dutch Disease literature built on the tradable-nontradable dichotomy and concentrated on the sectoral impact of terms of trade shocks [see Corden (1984) for a detail survey]. On the other hand, the intertemporal choice literature, following studies by Obstfeld (1982), Sachs (1981), and Svensson and Razin (1983), questioned the theoretical basis of the HLM effect and argued that in two-good models (imports and exports) household saving decisions should be derived from solutions to a dynamic optimization problem of selecting consumption and savings at different point in time. These studies concluded that the relationship between terms of trade and savings is sensitive to the duration of the terms of trade shocks. For instance, if improvements in the terms of trade are expected to be permanent, economic agents will revise upward their estimate of national income in current as well as future periods. In sharp contrast to the HLM effect, the higher level of income would lead to higher level of consumption with no effect on savings. On the other hand, if improvements are expected to be temporary, economic agents will smooth this windfall gain over future periods by raising savings. Hence the HLM effect holds in the presence of only transitory terms of trade shocks.

Later studies [Dornbusch (1983), Edwards (1989)] questioned the view that transitory shocks to the terms of trade have unambiguous effect on private savings. Using a three good

\footnotetext{
${ }^{7}$ For a survey of early works in this area, see Ostry and Reinhart (1992).
} 


\section{William Davidson Institute Working Paper 572}

(imports, exports, non-tradables) model, these studies showed that an adverse terms of trade shock can affect private savings in three different ways. First, it will lower the current national income relative to future national income (consumption-smoothing or HLM effect). Second, it will increase the price of current imports relative to future imports leading consumers to postpone their purchases, that is, save more (the consumption-tilting effect). Third, it will increase the price of imports relative to the price of the non-tradables thereby leading to an appreciation of the real exchange rate. This, in turn, will increase the consumption rate of interest and provide an incentive to postpone current consumption and increase savings (the real exchange rate effect). As pointed out by Cashin and McDermott (2002), in response to an adverse transitory terms of trade shock, private savings will increase (decrease) if the consumption smoothing effect dominates (is weaker than) the savingenhancing effects of the consumption-tilting and real exchange rate effects. ${ }^{8}$

In a recent paper, Agenor and Aizenman (2002) have suggested that terms of trade shocks can also lead to an asymmetric response in savings in the developing countries. Slumps and booms in commodity prices may trigger different response to welfare changes. Households may not be able to smooth consumption when faced with adverse shocks to the terms of trade due to the presence of, say, increased borrowing constraints in the international financial markets. Consequently, in order to maintain a smooth consumption path, economic agents may be forced to dissave by a larger amount than they would otherwise have. To the extent that domestic agents internalize the possibility of facing restrictive borrowing constraints during hard times, they may also consume less and save more in good times.

Given the recent terms of trade fluctuations experienced by the transition countries, it would be of particular interest to the policy makers to see what effect, if any, it has on the level of

\footnotetext{
${ }^{8}$ Ogaki, Ostry, and Reinhart (1996) have shown that in low income countries, where levels of income are near the subsistence level, consumption-tilting and real exchange rate effects have a relatively limited impact on savings. Their results provide support to the consumption smoothing view of HLM that transitory adverse disturbances in the terms of trade in these countries tend to lower private savings.
} 


\section{William Davidson Institute Working Paper 572}

private savings. This is more so given the fact that recent studies in this area have generally ignored the transition economies.

\section{Methodology}

Three issues need to be considered in selecting an estimation procedure. First, we want to allow for inertia in savings ratio that may arise from lagged effects of the explanatory variables on savings. ${ }^{9}$ Second, some regressors included in the equation such as real income growth and public savings may be jointly endogenous, i.e. correlated with the error term. Third, unobserved time- and country-specific factors may be correlated with the explanatory variables producing biased and inconsistent estimates.

To address these issues, our empirical strategy is based on a recently developed dynamic panel data technique. The generalized method of moments (GMM) technique, initially proposed in Hansen (1982) and later refined in Arellano and Bover (1995) and Blundell and Bond (1998) is used here for estimating a set of moment conditions to generate consistent and efficient estimators. ${ }^{10}$ The GMM estimator combines into a single system the regression equation in both changes and levels, each with its specific set of instrumental variables.

The methodology is briefly described in this section. Let the dynamic reduced-form savings regression equation be:

$$
\mathrm{y}_{\mathrm{i}, \mathrm{t}}=\beta_{1} \mathrm{y}_{\mathrm{i}, \mathrm{t}-1}+\beta_{2} \mathrm{X}_{\mathrm{i}, \mathrm{t}}+\eta_{\mathrm{i}}+\varphi_{\mathrm{i}, \mathrm{t}}
$$

where $y$ is the savings rate, $X$ represents a set of variables that potentially affect the savings rate and for which time and cross-sectional data are available, $\eta$ represents a set of unobserved time-invariant country specific effects, and $\varphi$ is the error term. Specifying the regression equation in difference form helps eliminate the country-specific effect and allows lagged

\footnotetext{
${ }^{9}$ This dynamic specification helps differentiate between short- and long-run effects on savings [See Loyza et al (2000)].
} 
levels of endogenous variables become valid instruments [Anderson and Hsiao (1982)].

Thus:

$$
\mathrm{y}_{\mathrm{i}, \mathrm{t}}-\mathrm{y}_{\mathrm{i}, \mathrm{t}-1}=\beta_{1}\left(\mathrm{y}_{\mathrm{i}, \mathrm{t}-1}-\mathrm{y}_{\mathrm{i}, \mathrm{t}-2}\right)+\beta_{2}\left(\mathrm{X}_{\mathrm{i}, \mathrm{t}}-\mathrm{X}_{\mathrm{i}, \mathrm{t}-1}\right)+\left(\varphi_{\mathrm{i}, \mathrm{t}}-\varphi_{\mathrm{i}, \mathrm{t}-1}\right)
$$

The first issue raised is the likely endogeneity of the explanatory variables, $X$, shown by the correlation between these variables and the error term. A second issue is the correlation of the error term in equation (2) with the differenced lagged dependent variable in the same equation. We control for joint endogeneity using instruments based on lagged values of the explanatory variables. Thus, instead of assuming that the explanatory variables be uncorrelated with the error term at all leads and lags (strict exogeneity), weak exogeneity is assumed. This allows for the possibility of simultaneity and reverse causation. Thus, current explanatory variables may be affected by past and current realizations of the dependent variable, but not by its future innovations [see Calderon et al (2001) and Loayza et al (2000)]. Under these assumptions, the following set of moment conditions are formulated and applied to the lagged savings rate and the set of regressors:

$$
\begin{array}{ll}
\mathrm{E}\left[\mathrm{y}_{\mathrm{i}, \mathrm{t}-\mathrm{k}}\left(\varphi_{\mathrm{i}, \mathrm{t}}-\varphi_{\mathrm{i}, \mathrm{t}-\mathrm{l}}\right)\right]=0 & \text { for } \mathrm{k} \geq 2, \mathrm{t}=3, \ldots \mathrm{T} \\
\mathrm{E}\left[\mathrm{X}_{\mathrm{i}, \mathrm{t}-\mathrm{k}}\left(\varphi_{\mathrm{i}, \mathrm{t}}-\varphi_{\mathrm{i}, \mathrm{t}-\mathrm{l}-}\right)\right]=0 & \text { for } \mathrm{k} \geq 2, \mathrm{t}=3, \ldots \mathrm{T}
\end{array}
$$

The GMM estimator based on equations (3) and (4) is known as the "difference estimator" [Calderon et al (1999)]. Despite being asymptotically consistent, this estimator has low asymptotic precision and large biases in small samples [Blundell and Bond (1998)]. ${ }^{11}$ To mitigate this concern, the estimator presented in Arellano and Bover (1995) is used. This estimator combines, in a system, regression equation in levels with the regression in differences.

\footnotetext{
${ }^{10}$ Studies using this method include Calderon et al (1999, 2001), Edison et al (2002), Fajnzylber et al (2002), Konings et al (2002), and Loayza et al (2000).

${ }^{11}$ The construction of the difference estimator eliminates the cross-country relationship between the savings rate and the regressors. Blundell and Bond (1998) have shown that, in the presence of persistence of the regressors over time, the lagged levels of these variables are weak instruments for the regression equation in differences. This leads to an increase in asymptotic inefficiency and small sample bias of the difference estimator.
} 


\section{William Davidson Institute Working Paper 572}

Unlike the difference regression, where country-specific effects are eliminated, the regression in levels only controls for the use of such effects through instrumental variables.

The instruments for the regression in differences are the lagged levels of the corresponding variables. Therefore, the moment conditions in equations (3) and (4) apply for the first panel of the system. For the second part, the appropriate instruments for the regression in levels are the lagged differences of the corresponding variables. The additional moment conditions for the regression in levels are given by: ${ }^{12}$

$$
\begin{array}{ll}
E\left[\left(y_{i, t-k}-y_{t-k-1}\right)\left(\eta_{i}+\varphi_{i, t}\right)\right]=0 & \text { for } k=1 \\
E\left[\left(X_{i, t-k}-X_{i, t-k-1}\right)\left(\eta_{i}+\varphi_{i, t}\right)\right]=0 & \text { for } k=1 .
\end{array}
$$

Following Arellano and Bond (1991) and Arellano and Bover (1995) and using the moment conditions given in equations (3)-(6), we employ the GMM technique to generate consistent estimates of the parameters.

The consistency of the estimator depends on whether the lagged values of the explanatory variables are valid instruments in the regression equation. We investigate this using two specification tests given in Arellano and Bond (1991) and Arellano and Bover (1995). ${ }^{13}$ The first is the Sargan test of overidentifying restrictions. It tests the overall validity of the instruments by analyzing the sample analog of the moment conditions used in the estimation process. The null hypothesis is that the instruments are not correlated with the residuals in the first-difference regressions. ${ }^{14}$ A non-rejection of the null hypothesis provides support to the model. ${ }^{15}$ The second specification test refers to the hypothesis that the error term is not serially correlated. In particular, we test for the order of serial correlation for the residual of the

\footnotetext{
${ }^{12}$ For a description of the assumptions under which these moment conditions hold, see Loayza et al (2000).

${ }^{13}$ For a simple description of these tests, see Calderon et al (2001). These two tests are also used in Fajnzylber et al (2002) and Loayza et al (2000).

${ }^{14}$ Under the null hypothesis, the asymptotic distribution of the test statistic is chi-square with $(m-q)$ degrees of freedom, where $m$ is the number of instruments and $k$ is the number of explanatory variables.

${ }^{15}$ Bowsher (2002) has recently argued that the excessive use of moment conditions in moderately large time series dimensions can cause the Sargan test to be undersized and have extremely low power. Interestingly, Bowsher found the alternative Exponential Tilting Parameter test generally possessed worse size properties than the
} 


\section{William Davidson Institute Working Paper 572}

regression in differences. As a first-order serial correlation is expected, we test the null hypothesis of absence of second-order serial correlation. Failure to reject the null hypothesis shows the original error term is serially uncorrelated.

\section{The Savings Equation}

Almost uniformly, the savings rate in the transition economies has been relatively stable in recent years after a strong rebound from the sharp decline at the beginning of the transition [IMF 2000a, Schrooten and Stephan (2002)]. Despite the different patterns of recovery within this group, the commonality of the behavior suggests a systematic response of savings to its determinants [Denizer and Wolf (2000)].

IV.1 The Basic Equation

Given the underlying hypothesis that saving behavior in transition economies do not differ markedly from that of market economies with similar fundamentals [Denizer and Wolf (2000), Schrooten and Stephan (2002)], we use an empirical savings function similar to IMF (2000a) and Schrooten and Stephan (2002) as the base for our estimation. The function includes a broad range of savings determinants. ${ }^{16}$ Thus

$\mathrm{PS}_{\mathrm{t}}=\alpha_{0}+\alpha_{1} \mathrm{PS}_{\mathrm{i}, \mathrm{t}-1}+\alpha_{2} \mathrm{RPCY}_{\mathrm{it}}+\alpha_{3} \mathrm{GRPCY}_{\mathrm{it}}+\alpha_{4} \mathrm{M} 2 / \mathrm{GDP}_{\mathrm{it}}+\alpha_{5} \mathrm{INF}_{\mathrm{it}}+\alpha_{6} \mathrm{PUBSAV}_{\mathrm{it}}+\alpha_{7} \mathrm{DEP}_{\mathrm{it}}$ $+\alpha_{8} \mathrm{PTOT}_{\text {it }}+\alpha_{9} \mathrm{TTOT}_{\text {it }}+\alpha_{10} \mathrm{VTOT}_{\text {it }}+\alpha_{11} \mathrm{DUMMY}$

Specifically, in the basic equation, the per capita savings rate (PS) is modeled as a function of the one-period lagged per capita savings rate $\left(\mathrm{PS}_{\mathrm{t}-1}\right)$, real per capita income (RPCY), real per capita GDP growth (GRPCY), level of monetization (M2/GDP), inflation rate (INF), the ratio of public savings to gross national disposable income (PUBSAV) and dependency ratio (DEP). To analyze

conventional Sargan test. This criticism of the Sargan test is likely inapplicable here as our time series is relatively small.

${ }^{16}$ IMF (2000a) and Schrooten and Stephan (2002) uses a similar set of determinants for savings in the transition economies. For an excellent summary of various determinants of savings and findings from previous empirical studies, see Loayza et al (2000). 
the impact of terms of trade, four variables (PTOT, TTOT, VTOT, DUMMY) are added to the basic equation. PTOT and TTOT are the permanent and transitory components of the terms of the trade, respectively; while VTOT measures its volatility. The dummy variable (DUMMY) captures the presence of any asymmetric effect of the terms of trade.

\section{IV.2 Rationale for the Explanatory Variables}

The lagged private savings rate can be an important predictor of the current savings rate as it captures the habit formation effects and measures the rate of partial adjustment of the desired savings propensity to its actual value. ${ }^{17}$ Real per-capita income is a major determinant of savings in both the permanent income and the life cycle hypotheses [Dayal-Gulati and Thimann (1997), Kent (1997), Lahiri (1989)]. However, the impact of income on savings has been inconclusive in theoretical models. The simple permanent income theory predicts that higher economic growth reduces private savings. In contrast, the intertemporal optimizing models, such as, the life-cycle model, suggest a positive relationship between national income and private savings. Most of the cross-country empirical studies find that permanent increase in income have a positive effect on private savings rate. $^{18}$

The growth rate of per capita GDP (GRPCY) captures the improvements in the standard of living and should have a positive impact on savings. The level of monetization is measured by the share of broad money in GDP. This is a realistic proxy for financial development and reform in the transition economies as those that have made the most progress in reforming their financial systems in terms of rehabilitation and privatization of the banking system, establishing and enforcing prudential banking regulations, and establishing functioning capital market are also

\footnotetext{
${ }^{17}$ Alessie and Lusardi (1997) consider models of habit formation and show that savings depend not only on future income changes and income risk, but also on past saving. There is also an econometric reason for including this variable. The error process in a dynamic specification suffers from a potential problem of serial correlation. This has important implication for both the validity test of the instruments used in the estimation process as well as its impact on the consistency of the estimates. In order to specify a dynamic regression with uncorrelated disturbances, lagged value of savings should be included as an additional control.

${ }^{18}$ See, for example, the papers by Blanchard and Fischer (1989) and Bosworth (1993).
} 


\section{William Davidson Institute Working Paper 572}

among those with the highest monetization ratios [UN (2001)]. The sign of this variable is ambiguous. As far as it represents the development of the financial system in the country, it should have a positive effect on savings. Zeldes (1989) has, however, argued that the monetization variable should have a negative sign as it captures the borrowing constraints faced by the consumers and thereby reduces their ability to smooth consumption through borrowing. The inflation (INF) variable, measured as the annual percentage change in the CPI, should have a negative impact on the savings rate as it reflects precautionary savings effect due to macroeconomic instability and income variability [Fischer (1993)].

Fiscal policy can potentially affect private savings through revenue policy (say, tax structure), expenditure policy (say, income distribution), or the extent of public savings. The rationale is to find out the extent to which the private sector in these countries internalize the government budget constraint and hence the extent to which a change in public savings lead to a change in private savings. Hence public savings is included here. The variable (PUBSAV) measures public savings as a ratio of GDP.

The dependency ratio (DEP) captures the life-cycle effect and is included to measure the impact of demographic variables on the savings rate. As aggregate data on private savings include both savings by the working population and dissaving by the retired, demographic changes with respect to the relative size of these two groups could also offset private savings. A number of countries in the sample have undergone dramatic demographic transition. Very low birth rates have lead to a precipitous drop in the fraction of the population under the age of fifteen. Combined with an increasingly mobile population, this has weakened an important source of support in old age - children. The variable (DEP) is included in the model and is measured as the ratio of the difference between the total population and the employed labor force to the total population. $^{19}$

\footnotetext{
${ }^{19}$ Further disaggregation of population by old and young age, to account for unequal income flows over the life cycle, would have been beneficial. But consistent data for all the countries was unavailable. Following Kraay
} 
Next, following Agenor and Aizenman (2002) and Cashin and McDermott (2002), a set of variables measuring the possible impact of terms of trade shocks are included in the model. The terms of trade is computed as the ratio of merchandise exports deflator (line 74 or line 76 in International Financial Statistics published by IMF) to the merchandise imports deflator (line 75 or line 76.x in the International Financial Statistics) with 1995 as the base year. ${ }^{20}$ The trend movement in the terms of trade (PTOT) picks up any permanent wealth effect over time and is estimated by the trend series obtained from a standard Hodrick-Prescott (HP) filter. ${ }^{21}$ Following Agenor and Aizenman (2002), the measure is weighted by the ratio of real exports to real GDP in order to capture the fact that the higher the share of exports in output, the higher is the impact of volatility in the terms of trade. The transitory component of the terms of trade (TTOT) measures the temporary shocks and is the filtered series obtained from the use of the HP filter. This variable is also weighted by the ratio of real exports to real GDP and is anticipated to have a positive impact on savings. A time varying measure of the terms of trade volatility (VTOT) is included as a proxy for income uncertainty. ${ }^{22}$ This should have a negative impact on savings.

(2000), estimations were also performed using a slight variation of this variable (ratio of population to employment). The results didn't change much.

${ }^{20}$ Based on a Referee's suggestion and following Otto (2003), we used a different measure of terms of trade the price of exports divided by the price of imports, where the price of export and import are measrued by their respective national accounts deflators (for goods and services). The data are taken from the World Bank's World Tables database. However, initial estimations provided results which are qualitatively similar to those given in the paper.

${ }^{21}$ The HP filtering technique can be described as follows. Let a seasonally adjusted variable, $\mathrm{y}_{\mathrm{t}}$ be written as the sum of an unobserved trend component, $\mathrm{y}_{\mathrm{t}}{ }_{\mathrm{t}}$, and a residual cyclical component, $\mathrm{y}_{\mathrm{t}}^{\mathrm{r}}$. The HP filter uses an adjustment method where the trend component moves continuously and adjusts gradually. The trend component is selected by minimizing the sum of the squared deviations from the observed series, subject to the constraint that changes in $\mathrm{y}^{*}$ vary gradually over time. Thus,

$$
\underset{\mathrm{t}=1}{\operatorname{Min} \sum_{\mathrm{t}}}\left(\mathrm{y}_{\mathrm{t}}-\mathrm{y}_{\mathrm{t}}\right)^{2}+\underset{\mathrm{t}=2}{\lambda \sum^{\mathrm{T}}\left[\left(\mathrm{y}_{\mathrm{t}+1}^{*}-\mathrm{y}_{\mathrm{t}}\right)-\left(\mathrm{y}_{\mathrm{t}}-\mathrm{y}_{\mathrm{t}-1}\right)\right]^{2}}
$$

The lagrange multiplier, $\lambda$, is the smoothing component such that higher values of $\lambda$ lead to a more smooth trend series. The use of the HP filter has, however, been criticized on the ground that it removes potentially valuable information from the time series [King and Rebelo (1993)]. Moreover, the difficulty in using index numbers for terms of trade in panel data is generally acknowledged. The use of the HP filter implicitly assumes that if a terms of trade spectrum is defined from strong to weak, all countries will be at the midpoint in 1995, the base year. But in reality it may not be the case. To alleviate this problem, estimations were also performed using terms of trade ratios. The results were not significantly different from those reported in the paper.

\footnotetext{
${ }^{22}$ Following the method discussed in Chowdhury (1993), the variable is constructed by the moving sample standard deviation of the growth rate of the terms of trade
} 


\section{William Davidson Institute Working Paper 572}

The presence of an asymmetric effect of terms of trade on saving is captured by a dummy variable (DUMMY). As suggested in Agenor and Aizenman (2002), the variable used is an interactive dummy which takes the value of unity times the logarithm of the permanent component of the terms of trade, weighted by the ratio of exports to GDP, when that component increases above its previous value, and zero otherwise.

In addition to the basic set of regressors included in equation (7), estimations are also performed using several alternative determinants of savings. Specifically, four variables are selected. Income uncertainty (VINC) is represented by the moving sample standard deviation of the growth rate of per capita real income. This variable is expected to have a positive impact on the savings rate. Foreign savings $(\mathrm{CAB})$, a proxy for international borrowing and therefore for international financial integration, is measured by the ratio of current account balance to GDP. A negative sign for this variable refers to the net amount of foreign savings which have been attracted, in addition to domestic savings; while a positive sign suggests substitutability of the two variables. ${ }^{23}$

Two price variables representing the financial market are also used. First, the real interest rate (RINT) is measured as the difference between one year time deposit rate and the expected rate of inflation. ${ }^{24}$ Second, following Koivu (2002), the difference between the lending and deposit rates in banking sector (MARGIN) is used as an estimator of banking efficiency. Koivu (2002) has shown that a decrease in this rate differential due to a fall in the transaction costs

\footnotetext{
$\mathrm{k}$

$\mathrm{V}_{\mathrm{t}}=\left[(1 / \mathrm{k}) \sum_{\mathrm{i}=1}\left(\log \mathrm{Q}_{\mathrm{t}+\mathrm{i}-1}-\log \mathrm{Q}_{\mathrm{t}+\mathrm{i}-2}\right)^{2}\right]^{1 / 2}$ where $k=3$ is the order of the moving average. Estimations have also been performed using $k=2$. The conclusion appears to be robust irrespective of the value of $k$.

${ }^{23}$ The foreign savings variable has been included in a number of studies [Loayza et al (2000), and Masson et al (1998), and Schrooten and Stephan (2002)] but excluded in others [Agenor and Aizenman (2002)].

${ }^{24}$ To overcome the problem of unobservable expected inflation rate, it is assumed that expectations are formed according to the adaptive expectation model, that is, $\mathrm{p}_{\mathrm{t}}^{\mathrm{e}}-\mathrm{p}_{\mathrm{t}-1}^{\mathrm{e}}=\mathrm{b}\left(\mathrm{p}_{\mathrm{t}}^{\mathrm{e}}-\mathrm{p}_{\mathrm{t}-1}^{\mathrm{e}}\right)$ where $b$ is the coefficient of expectations such that $0<b<1$.
} 
would lead to a higher share of savings going to investment, thereby accelerating economic growth.

\section{The Estimation Results}

\section{V.1 Baseline Regression Results}

Estimations have been performed using annual unbalanced panel data for 21 countries in Eastern Europe and the former Soviet Union for the 1993-2001 sample period. ${ }^{25}$ Data on the private and public savings rate have been taken from the Economic Survey of Europe published by the United Nations Economic Commission for Europe; while data on terms of trade, M2, prices and current account are taken from the International Financial Statistics published by the International Monetary Fund. Data on the dependency variable has been taken from the World Bank's World Development Indicators. Data on all the other variables have been taken from various issues of the Transition Report published by the European Bank for Reconstruction and Development.

Table 2 reports the results of the regression equations for private savings using alternative estimators on the full sample and the basic specification. In order to facilitate comparison with the GMM dynamic panel technique, estimates using cross-section data (column 1) and pooled annual data in static specification without the lagged savings rate (column 2) are presented. Neither of these two specifications take into account the issues of endogeneity and unobserved country-specific effects. In both cases, the rejection of the null hypothesis for both the error serial correlation tests indicate that the estimated coefficient in these

\footnotetext{
${ }^{25}$ Countries in the sample include Bulgaria, Croatia, Czech Republic, Hungary, Poland, Romania, Slovakia, Slovenia, Macedonia, Estonia, Latvia, and Lithuania from the Eastern Europe and Baltic States category, while the FSU countries include Armenia, Azerbaijan, Belarus, Georgia, Kazakhstan, Moldova, the Russian Federation, Ukraine, and Uzbekistan. Availability of data constrained the choice of countries, sample period, and variables.

To minimize balance problems, countries included in the sample have at least five observations. We started with 168 observations. Since three observations per country were used for constructing the instruments, the basic regression sample consists of 105 observations.
} 


\section{William Davidson Institute Working Paper 572}

specifications cannot offer valid conclusions as relevant variables with high over-time persistence are not included.

The third regression shown in column 3 is the basic dynamic specification which includes the lagged savings term. Note that consistent with our previous discussion, the panel estimates, by construction exhibit first-order serial correlation. However, our primary concern is the presence of second order serial correlation. Both the hypotheses of lack of second-order residual serial correlation and of no correlation between the error term and the instruments (Sargan test) cannot be rejected indicating support for the dynamic specification as well as for the instruments used in the estimation process. Results from the Wald test of joint significance show that the coefficients are jointly significant.

The coefficient on the lagged private savings rate is, as expected, positive. The value of 0.529 shows the presence of a large degree of persistence. In fact, the view that past savings is an important predictor of current savings in the transition economies appear to be confirmed. This also implies that, if all changes in any of the explanatory variables is permanent, its long run effect is exactly 2.12 times higher than the short-run effect. The positive and statistically significant coefficient on the per-capita income variable implies that countries with higher per capita income tend to save relatively more than countries with lower per capita income. Confirming the theoretical relationship as shown in an intertemporal model, such as, the life cycle hypothesis, this may also explain why savings have been higher in the East European and Baltic states relative to the countries of the former Soviet Union. The business cycle effect, measured by the coefficient on the GDP growth rate, holding the per capita income constant, is statistically insignificant.

The financial depth variable (measured by the ratio of M2 to GDP) has a highly significant negative impact on private savings. When the volume of M2 rises by 1 percent of GDP, the private savings rate decreases by 0.24 percentage point. This result confirms the widely held 


\section{William Davidson Institute Working Paper 572}

view that financial reform may stimulate consumption by relaxing domestic liquidity constraints through, say, increased access to bank credit, and thus reduce the propensity to save. ${ }^{26}$ Similar results have been reported for Sub-Saharan Africa [Agenor and Aizenman (2002)], and 69 developed and developing countries [Loayza et al (2000)]. ${ }^{27}$ Inflation has a positive impact on savings. An increase of inflation by 10 percentage points raises private savings by eight-tenths of one percentage point. As it represents macroeconomic uncertainty, the results show that increased uncertainty about the aggregate economy and expectation of further price increases induces agents to lower their current consumption and increase precautionary savings.

The coefficient on public savings is negative and statistically significant suggesting that the private sector internalize the government's budget constraint. The short-term coefficient is 0.176 giving a permanent long term value of 0.373 . Since the coefficient is statistically less than one, we can reject Ricardian equivalence for the full sample.

The dependency ratio variable has the expected negative sign but is marginally significant in the equation. IMF (2000a) reported a positive impact of dependency rate on domestic savings in Poland while Denizer and Wolf (2000) found the impact to be negative but insignificant in a group of 25 transition countries during the early years of transition. The lack of a strong negative effect in the transtion economies may suggest that substantial changes in the education, social welfare and pension systems have led to an expectation of decline in these benefits and consequently economic agents are responding by not lowering their own provision for education and retirement. ${ }^{28}$

\footnotetext{
${ }^{26}$ As pointed out by an anonymous Referee, the financial depth variable is also a measure of financial wealth for the private sector in the early years of the transition. It, therefore, follows that savings will rise as accumulated wealth falls in real terms.

${ }^{27}$ Chowdhury (2001a) and Jappelli and Pagano (1995) also reports a negative relationship between financial reform and private savings in the developing countries.

${ }^{28}$ Collins (1991) has argued that in order for savings rate to be negatively associated with dependency rates require the assumption that the economy is growing. Following her suggestion, the regression has been
} 


\section{William Davidson Institute Working Paper 572}

Next, consider the variables of interest for this study. Both the permanent and temporary components of the terms of trade are positive and statistically significant. This is similar to the results reported for a group of developing countries in Masson et al (1998) and both developed and developing countries in Loayza et al (2000). Moreover, the magnitude of the coefficient on the temporary component is much larger than that of the permanent component. ${ }^{29}$ This reflects the lack of access to foreign borrowing that many of the transition economies have faced during the last decade. The short-term coefficient on the transitory variable is 0.274 , so the long-term effect is around 0.582 . As both these values are significantly less than one, there is an incomplete pass-through in the system. This may be due to the inability of the households to fully realize the degree of persistence of terms of trade shock at the moment they occur. Agenor and Aizenman (2002) reports similar findings for Africa.

The volatility of the terms of trade has a statistically significant negative impact on savings. This is contrary to the findings as reported in Agenor and Aizenman (2002). The dummy variable has the anticipated positive sign but is small in magnitude. This suggests that although there is evidence of an asymmetric impact of terms of trade shocks, the size of the impact is relatively small in the transition economies.

\section{V.2 Alternative Determinants}

In this subsection, the basic savings equation given in (7) is extended by including an augmented set of explanatory variables. The obvious candidates to form part of this group are those that are explicitly implied by economic theory and have been used in empirical studies. The potential determinants are each added separately to the basic equation given in Table 2 (equation 3). The results are reported in Table 3. In the first equation (column 1), a proxy for 


\section{William Davidson Institute Working Paper 572}

income uncertainty, measured as the moving sample standard deviation of per capita GDP growth, is added. The estimated coefficient has the positive sign as is expected from the precautionary saving motive and is significant. This provides evidence that in response to an increase in the volatility of income, due to, say, an increase in the probability of being unemployed, an economic agent will increase private savings in order to hedge against the greater probability of a large negative income shock in the future. In the presence of the income volatility variable, the inflation variable loses some of its significance indicating that the income variable is capturing some of the inflationary effects of macro uncertainty. In the second equation (column 2), the current account deficit is added. The coefficient is positive indicating that a decrease in the current account balance (or an increase in foreign savings) is partially balanced by a fall in private savings. The short-term coefficient is 0.154 while the long-term effect is 0.307 showing that in the long run a 1 percent increase in foreign savings as a proportion of GDP would lead to approximately a three-tenths of one percent decline in the savings rate.

The next variable added to the basic equation is the real interest rate (column 3 ). The coefficient is negative but statistically insignificant. ${ }^{30}$ This means that the positive substitution effect of an increase in real interest rate is cancelled out by the negative income effect. Further analysis showed that the real interest rate variable is highly correlated with the inflation rate with a correlation coefficient of 0.65 . This implies that during the sample period considered, the nominal rates adjusted rather slowly to changes in economic fundamentals

\footnotetext{
${ }^{29}$ When Cashin and McDermott (2002) decomposed terms of trade movements in 5 OECD countries into their permanent and temporary components, they found the temporary component to be large for all countries accounting for about half of the variance of the quarter to quarter changes in the terms of trade.

${ }^{30}$ Ogaki et al (1996) and Elbadawi and Mwenga (1999) also found private savings to be insensitive to changes in the real interest rates in a number of low- and middle-income developing countries.
} 


\section{William Davidson Institute Working Paper 572}

and that, on average, changes in inflation were dominating the movements in the real interest rates. $^{31}$

The fourth variable, interest margin, is a proxy for banking efficiency in these countries. The coefficient has a positive sign and is statistically significant confirming the economic implications discussed in Koivu (2002). Financial reform has improved banking efficiency. This, in turn, has raised conspicuous consumption thereby lowering private savings. The value of the lagged savings rate varies between 0.498 and 0.537 in the four equations. The degree of persistence remains strong in the presence of additional regressors. The values for the other explanatory variables in the Table are qualitatively similar to those found in the basic regression equation given in Table 2.

\section{V.3 Sensitivity Analysis}

As the transition countries have experienced wide variation in their growth process, the robustness of the results to regional coverage is investigated. First, the basic model is reestimated while removing one country at a time. The process ensures that any undue effects of an outlier country will be reflected by significantly different results for the sample omitting that county. Although the coefficient estimates (not reported here) varied slightly, there is no qualitative change in the results.

Next, it is investigated if the relationship between various significant measures of terms of trade shocks and the savings rate is robust or fragile to small changes in the conditioning information set. The reliability and robustness of the relationship are evaluated using a version of Leamer's (1983) extreme bounds analysis as developed in Levine and Renelt (1992). ${ }^{32}$ In particular, the following regression is estimated

\footnotetext{
${ }^{31}$ In addition to government controls, the rigidity in nominal interest rates has been due to a number of factors, including the oligopolistic nature of the domestic banking system, inadequate banking supervision, and relatively thin domestic money, credit, and capital markets.

${ }^{32}$ See Chowdhury (2001b) and the references therein for an application of this procedure. Radulescu and Barlow (2002) employed the extreme bound analysis for a group of transition economies.
} 


$$
\mathrm{PS}=\mathrm{a}+\mathrm{b}_{\mathrm{i}} \mathbf{I}+\mathrm{c}_{\mathrm{z}} \mathbf{Z}+\mathrm{u}
$$

Where $P S$ is the savings rate, $\boldsymbol{I}$ is the set of base variables of interest included in all regressions and $\boldsymbol{Z}$ is a subset of variables selected from a pool of potentially important explanatory variables of savings. We first run a base regression that includes only the $\boldsymbol{I}$ variables. Then we compute the regression results for all possible linear combinations of up to three $\boldsymbol{Z}$ variables and identify the lowest and highest values for the coefficients in the $\boldsymbol{I}$ vectors of variables that cannot be rejected at the 5 percent level of significance. If the estimated coefficients remain significant over this procedure, the correlation is said to be 'robust'. The 'extreme bounds' are the highest estimated correlation plus two standard errors and the lowest minus two standard errors. If the coefficient fails to be significant in some regression, the correlation is termed as 'fragile'.

Four variables earlier found to be statistically significant are included in the $\boldsymbol{I}$ vector-TTOT, PTOT, VTOT, and PS(-1). The pool from which the set of three control variables $\boldsymbol{Z}$ is drawn includes all the remaining ten explanatory variables used in Tables 1 and 2. During estimation, we select three variables from the pool of ten variables each time, add these three variables to the base regression of four variables, and see whether the parameters in the base regression are stable or not. The extreme bound results are given in Table 4. The GMM system estimator results appear to be robust. The four key variables keep the right sign, remain significant, and have values for the estimated coefficient that are consistent with those reported in the paper. For PS(-1), PTOT, TTOT, and VTOT the ranges are $(0.575,0.662)$, $(0.041,0.092),(0.125,0.206)$, and $(-0.244,-0.296)$, respectively. In summary, the coefficient estimates are fairly stable and insensitive to various extra regressors.

V.4 Country Groupings 


\section{William Davidson Institute Working Paper 572}

Given the differences in institutional characteristics and macro performance during the transition process, I then reestimate the model separately for three groups - the countries in line to join the European Union (EU Accession Countries), the countries in Eastern Europe and the Baltic States, and the former Soviet Union (FSU). ${ }^{33}$

These results are given in Table 5. For purposes of comparison, the results from the basic equation for the entire sample countries is reproduced in column 1 . The coefficient on the lagged private savings is positive and statistically significant in all three country groups. The value varies from a low of 0.466 in the EU Accession countries to a high of 0.616 in the FSU indicating the presence of a large degree of persistence in these countries. Although there is no major difference among the other regression results for the three groups, a number of intriguing nuances in the pattern of savings in the three groups are evident. The coefficient on public savings is negative and statistically significant in all three groups showing that the private sector in these countries internalize the government budget constraints. However, the short-run (long-run) magnitude of this effect is $-0.275(-0.515)$ and $-0.214(-0.41)$ in the Accession countries and Eastern European countries, respectively. This is far below the oneto-one relationship suggested by the simple Ricardian equivalence doctrine. On the other hand, the short- and long-run coefficients for the FSU countries are -0.378 and -0.984 , respectively. Hence, in the long run we cannot reject the Ricardian equivalence for these countries. The coefficient is very close to negative unity suggesting that a decline in public savings is matched by an increase in private savings. This provides support to Barro's (1974) argument that spending is unaffected by tax cuts, thus savings would increase to pay for future tax increases.

\footnotetext{
${ }^{33}$ Although the division is arbitrary and the countries within the three groups are not homogenous, it seems to be a natural choice for a number of reasons. First, economic decline in the East European and Baltic countries (the EU Accession countries is a subset of this group) in the early 1990s was, on average, less profound and persistent than that in the FSU. Second, in contrast to the FSU, most of the countries in the other two groups already had at least some elements of the market economy (e.g., a private sector) before the transition. Third,
} 


\section{William Davidson Institute Working Paper 572}

The absolute value of the coefficients of the per capita GDP and monetization variables are much higher in the FSU countries than in the other two groups, indicating that private savings in the former Soviet Union countries are more sensitive to changes in these two variables. The monetization variable has important policy implications in terms of prioritizing financial reforms in these countries. Countries with a relatively more developed financial system tend to generate a lower level of private savings. In other words, the availability of more credit instruments tend to raise the consumption level of the consumers. This finding supports the UN (2001) view that any further catching up in these variables (considering the fact that average per capita income level and monetization in the FSU are below those in the other two groups) might be expected to produce an even faster rate of catching up in private savings. The behavior of the variables of interest - permanent and temporary components of terms of trade shocks, its variability and the dummy variable measuring asymmetric shocks - show some differences. All the variables are positive and statistically significant. However, the magnitude of each of the variables is smaller in the FSU than in the other two country groupings. This seems to be counter-intuitive. Given that the trade in FSU countries are more dependent on primary commodities, terms of trade shocks should have a larger impact on private savings in these countries.

\section{Conclusion}

Using data from twenty-one transition economies, this paper analyzes the impact of terms of trade shocks on private savings after accounting for other determinants. Given the absence of efficient domestic credit and capital markets and limited access to international financial markets, economic agents in the transition economies are subject to tight credit constraints which are more pronounced during bad state of nature. Thus, adverse shocks to commodity

social safety nets in the East European and Baltic countries during the sample period have been much stronger than in FSU. See Ivaschenko (2002) on this issue. 


\section{William Davidson Institute Working Paper 572}

prices in world market force them to reduce savings by a larger amount than they would otherwise have. The opposite happens during the good times. As the households internalize the likelihood of facing binding borrowing constraints during bad times, they may also lower consumption and save more during good times.

The empirical results confirm the findings reported in IMF (2000a) that most of the determinants of savings identified in the mainstream literature also apply to the transition economies. A number of more specific conclusions can also be derived. First, private savings rate is highly persistent in these economies. The effect of a change in one of the determinants of savings is fully realized only after a number of years. Long-term responses are approximately two times larger than the short-term responses.

Second, private savings rate rise with the level of real per capita income. So policies that stimulate development can indirectly raise savings rate. Third, financial reform has adversely affected private savings in the transition economies. Larger financial depth, higher real interest rates, and interest rate margin changes fail to increase the private savings rate. The adverse effect is more pronounced in the FSU than in the East European and Baltic states. Reform in the financial sector has stimulated consumption by relaxing domestic liquidity constraints through, say, increased access to bank credit, and thus reduced the propensity to save.

Fourth, macroeconomic instability, measured by inflation rate causes an increase in the precautionary motive to save. Similar behavior is evident when volatility of income is introduced in the model. The move from a cradle-to-grave system of state-guaranteed income to market determined wages, and the advent of high inflation and high unemployment, along with cuts in public benefits have raised income uncertainty and changed expected future 


\section{William Davidson Institute Working Paper 572}

income profiles in these countries [Denizer et al (2002)]. The results in this paper show that households have responded by increasing precautionary savings.

Fifth, the private sector internalizes the government's budget constraint. The Ricardian equivalence is rejected for the East European and Baltic states but not for the FSU countries. In the latter group, public debt issues are macroeconomically indistinguishable from tax increases, thus changes in public savings is offset by an equal and opposite change in private savings. Sixth, a marginally negative impact of an increase in the dependency rate on private savings is evident suggesting that a smoothing out of uneven income flows over the life cycle may not be the main motive for saving.

Finally, the variables of primary interest for this study. In contrast to the intertemporal choice literature, this paper finds the permanent component of the terms of trade to have a significant positive impact on private savings. Transitiory movements in the terms of trade also have a significant positive impact and a larger magnitude than the permanent component. This reflects the lack of access to foreign borrowing that many of the transition economies have faced during the last decade. Although the impact of terms of trade shocks are found to be asymmetric in the transition economies, the magnitude of the impact appears to be small. 
Table 1a

Merchandise Trade of Eastern Europe, the Baltic and the former Soviet Union Countries By Major Product Groups

\begin{tabular}{lcrc} 
& \multicolumn{2}{c}{ Value } & \multicolumn{2}{c}{ Share } \\
\cline { 4 - 4 } & Exports & Exports & Imports \\
\hline Product Group & & & \\
$\quad$ Agricultural products & 25 & 32.6 & 10.5 \\
Mining Products & 93 & 56.4 & 74.7 \\
Manufactures & 161 & & \\
\hline
\end{tabular}

Note: in billion dollars and percentages

Source: UNCTAD

$\underline{\text { Table } 1 \mathrm{~b}}$

Annual Percentage Change in Oil and Non-oil Commodity Prices, 1981-2001

\begin{tabular}{lccccccc}
\hline Commodity Group & $1981-90$ & $1991-95$ & 1997 & 1998 & 1999 & 2000 & 2001 \\
\hline & & & & & & & \\
Non-oil Commodites & -2.3 & 4.1 & 2.2 & -15.7 & -6.3 & 1.8 & -5.4 \\
$\quad$ Agriculture & -3.2 & 5.6 & 2.5 & -16.2 & -5.2 & 2.0 & -6.9 \\
$\quad$ Metals and Minerals & 0.5 & 0.3 & 1.2 & -16.2 & -10.3 & 12.0 & -9.6 \\
$\quad$ Fertilizers & -2.5 & 0.7 & -0.1 & 2.0 & -5.2 & -5.3 & -5.8 \\
Petroleum & -4.7 & -5.6 & -6.2 & -31.8 & 37.5 & 57.1 & -14.1 \\
& & & & & & & -
\end{tabular}

Note: a/ Manufactures Unit Value Index

Sources: World Bank, Global Development Finance, 1999; IMF, World Economic Outlook, April 2003; author's calculation. 
$\underline{\text { Table } 2}$

Private Savings and Terms of Trade: Alternative Estimators

\begin{tabular}{|c|c|c|c|}
\hline Estimator & $\begin{array}{c}(1) \\
\text { OLS-CS }\end{array}$ & (2) & $\begin{array}{c}\text { (3) } \\
\text { GM-Syster }\end{array}$ \\
\hline Regression & Levels & Levels & Levels-Differ \\
\hline Instruments & & & Difference-L \\
\hline $\mathrm{PS}(-1)$ & - & - & $\begin{array}{l}0.529 \\
(5.44)\end{array}$ \\
\hline RPCY & $\begin{array}{r}0.521 \\
(4.33)\end{array}$ & $\begin{array}{r}0.424 \\
(3.76)\end{array}$ & $\begin{array}{r}0.179 \\
(6.20)\end{array}$ \\
\hline GRPCY & $\begin{array}{r}0.202 \\
(0.66)\end{array}$ & $\begin{array}{l}0.248 \\
(1.25)\end{array}$ & $\begin{array}{l}0.287 \\
(1.57)\end{array}$ \\
\hline M2/GDP & $\begin{array}{c}0.181 \\
(1.76)\end{array}$ & $\begin{array}{l}-0.202 \\
(2.63)\end{array}$ & $\begin{array}{l}-0.244 \\
(4.81)\end{array}$ \\
\hline INF & $\begin{array}{l}-0.163 \\
(1.88)\end{array}$ & $\begin{array}{l}-0.249 \\
(2.50)\end{array}$ & $\begin{array}{l}0.086 \\
(2.04)\end{array}$ \\
\hline PUBSAV & $\begin{array}{l}-0.187 \\
(2.90)\end{array}$ & $\begin{array}{l}-0.162 \\
(3.11)\end{array}$ & $\begin{array}{l}-0.176 \\
(4.92)\end{array}$ \\
\hline DEP & $\begin{array}{r}0.230 \\
(1.05)\end{array}$ & $\begin{array}{l}0.072 \\
(0.61)\end{array}$ & $\begin{array}{l}-0.303 \\
(1.99)\end{array}$ \\
\hline PTOT & $\begin{array}{l}-0.051 \\
(1.22)\end{array}$ & $\begin{array}{l}0.021 \\
(0.74)\end{array}$ & $\begin{array}{l}0.076 \\
(2.55)\end{array}$ \\
\hline TTOT & $\begin{array}{r}0.067 \\
(2.05)\end{array}$ & $\begin{array}{l}0.042 \\
(2.32)\end{array}$ & $\begin{array}{l}0.274 \\
(3.18)\end{array}$ \\
\hline VTOT & $\begin{array}{l}-0.041 \\
(2.54)\end{array}$ & $\begin{array}{l}0.007 \\
(1.97)\end{array}$ & $\begin{array}{l}-0.202 \\
(3.66)\end{array}$ \\
\hline DUMMY & $\begin{array}{r}0.001 \\
(1.57)\end{array}$ & $\begin{array}{l}0.001 \\
(1.63)\end{array}$ & $\begin{array}{l}0.011 \\
(4.15)\end{array}$ \\
\hline No. of Observations & 21 & 168 & 105 \\
\hline S.E.E. & 0.088 & 0.094 & 0.079 \\
\hline Wald Test & 0.000 & 0.000 & 0.000 \\
\hline Sargan Test & - & - & 0.288 \\
\hline $\begin{array}{l}\text { Serial Correlation } \mathrm{Te} \\
1^{\text {st }} \text { order } \\
2^{\text {nd }} \text { order }\end{array}$ & $\begin{array}{l}0.002 \\
0.004\end{array}$ & $\begin{array}{l}0.090 \\
0.091\end{array}$ & $\begin{array}{l}0.048 \\
0.536\end{array}$ \\
\hline
\end{tabular}

Note: Figures in parentheses are the absolute values of the t-statistics which are computed with heteroskedasticity-consistent standard errors. The p-values for the Wald Test, Sargan Test, and First- and Second-order Serial Correlation are given. 
William Davidson Institute Working Paper 572

$\underline{\text { Table } 3}$

Private Savings and Terms of Trade: Alternative Determinants

$\underline{\text { Variables }}$

PS(-1)

RPCY

GRPCY

M2/GDP

INF

PUBSAV

DEP

PTOT

TTOT

VTOT

DUMMY

VINC

$\mathrm{CAB}$

RINT

MARGIN

No. of Obs.

S.E.E.

Wald Test

Sargan Test

Serial Correlation Test

$1^{\text {st }}$ order

$2^{\text {nd }}$ order

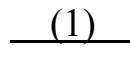

0.502

(3.63)

0.222

(4.13)

0.099

(1.29)

$-0.210$

(4.63)

0.087

(1.97)

$-0.108$

(3.79)

$-0.306$

(2.10)

0.009

(2.22)

0.218

(3.68)

0.011

(2.95)

0.088

(2.46)

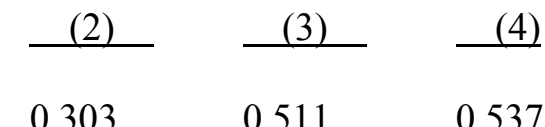

(3.04)

0.075

(4.63)

0.176

(2.17)

$-0.175$

(3.94)

0.190

(3.58)

$-0.130$

(1.68)

0.007

(1.99)

0.014

(2.19)

$-0.085$

(2.99)

0.006

(2.20)

0.154

(2.96)

$-0.033$

(1.43)

0.094

(2.32)

$\begin{array}{llll}105 & 105 & 105 & 105\end{array}$

$\begin{array}{llll}0.085 & 0.104 & 0.081 & 0.081\end{array}$

$\begin{array}{llll}0.000 & 0.000 & 0.000 & 0.000\end{array}$

$\begin{array}{llll}0.239 & 0.264 & 0.305 & 0.431\end{array}$

$\begin{array}{llll}0.038 & 0.051 & 0.029 & 0.041\end{array}$

$\begin{array}{llll}0.309 & 0.448 & 0.366 & 0.502\end{array}$

Note: See notes to Table 1. 


\section{William Davidson Institute Working Paper 572}

\section{Table 4}

Results from the Extreme Bound Analysis

\begin{tabular}{llllll}
\hline Variable & Bound & $\mathrm{b}_{\mathrm{i}}$ & $\begin{array}{c}\text { Sargan } \\
\text { Test }\end{array}$ & $\begin{array}{l}1^{\text {st }} \text { Order } \\
\text { Ser. Corr. }\end{array}$ & $\begin{array}{l}2^{\text {nd }} \text { Order } \\
\text { Ser. Corr. }\end{array}$ \\
\hline \multirow{3}{*}{ PS(-1) } & High & $0.662(4.16)$ & 0.19 & 0.00 & 0.16 \\
& Base & $0.614(4.59)$ & 0.20 & 0.00 & 0.23 \\
& Low & $0.575(4.13)$ & 0.25 & 0.00 & 0.34 \\
PTOT & High & $0.092(2.18)$ & 0.46 & 0.04 & 0.55 \\
& Base & $0.063(2.09)$ & 0.42 & 0.05 & 0.51 \\
& Low & $0.041(2.17)$ & 0.39 & 0.04 & 0.33 \\
TTOT & High & $0.206(3.85)$ & 0.39 & 0.02 & 0.63 \\
& Base & $0.155(3.46)$ & 0.42 & 0.02 & 0.61 \\
& Low & $0.125(3.71)$ & 0.40 & 0.03 & 0.52 \\
VTOT & High & $0.296(3.17)$ & 0.25 & 0.06 & 0.36 \\
& Base & $0.263(3.73)$ & 0.30 & 0.06 & 0.41 \\
& Low & $0.244(3.39)$ & 0.36 & 0.04 & 0.39
\end{tabular}

Note: The base ' $b$ ' is the estimated coefficient of the I-variable in equation (8) when private savings rate is regressed, using 2 SLS, on the I and Z variables. The high ' $b$ ' is the estimated coefficient from the regression with the extreme high bound $\left(b_{i}+\right.$ two standard deviations); the low ' $b$ ' is the coefficient from the regression with the extreme lower bound. Only the absolute values of ' $b$ ' coefficient are reported. The figures in parentheses are absolute values of the t-statistics which are computed with heteroskedasticity-consistent standard errors. 


\section{Table 5}

Private Savings and Terms of Trade Shocks: Alternative Country Groupings

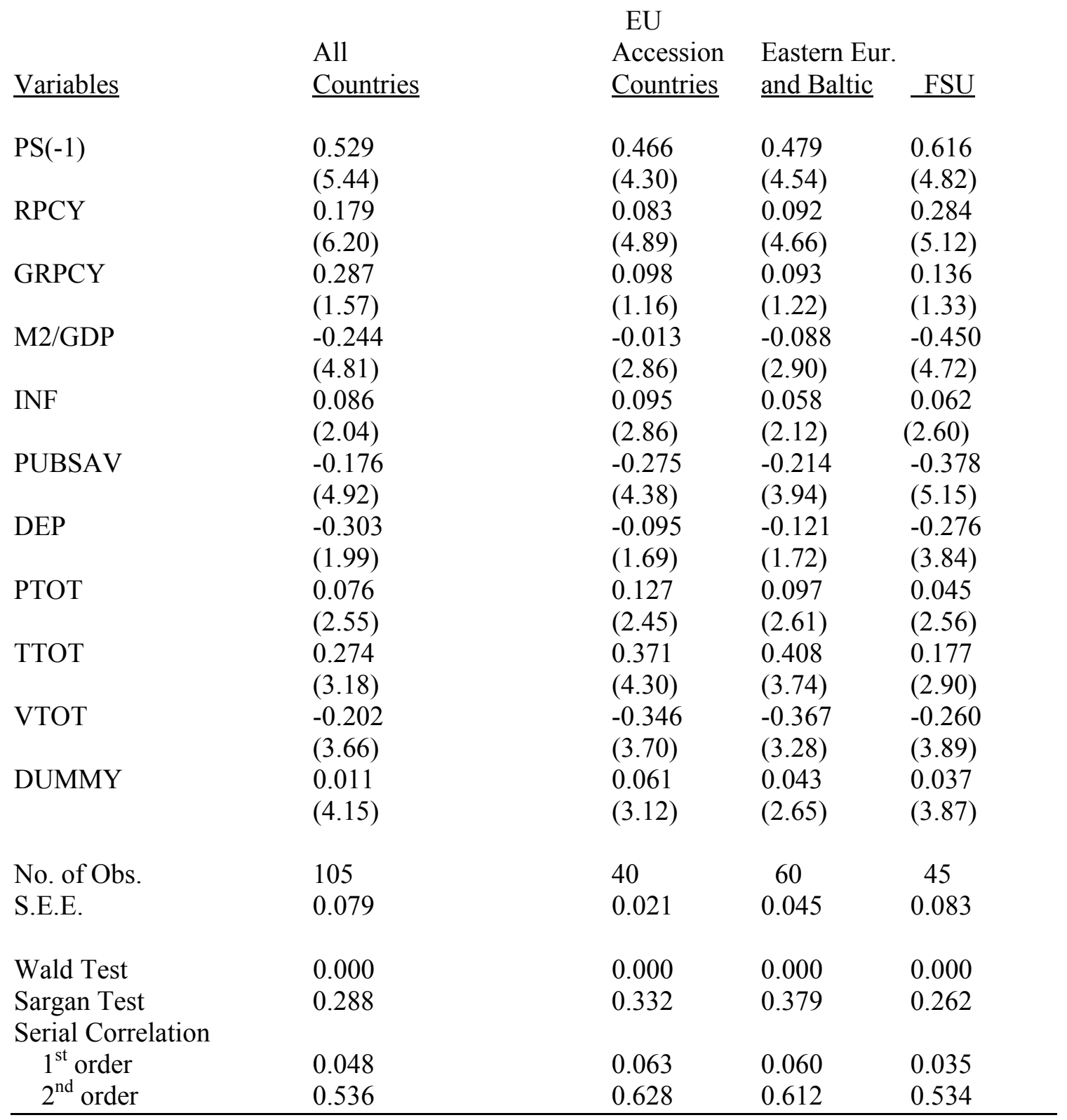

Note: $\quad$ Countries in the 'EU Accession Countries' category include Czech Republic, Hungary, Poland, , Slovakia, Slovenia, and the three Baltic states - Estonia, Latvia, and Lithuania. The 'Eastern Europe and Baltic States' group includes, in addition to the Accession countries, Bulgaria, Croatia, Macedonia FYR, and Romania. The 'former Soviet Union' (FSU) countries include Armenia, Azerbaijan, Belarus, Georgia, Kazakhstan, Moldova, the Russian Federation, Ukraine, and Uzbekistan. Availability of data constrained the choice of countries, sample period, and variables. The p-value for the Wald Test, Sargan Test, and First- and Second-order Serial Correlation are given. 


\section{$\underline{\text { References }}$}

Agenor, P., and J. Aizenman, (2002) "Savings and the Terms of Trade under Borrowing Constraints," Forthcoming, Journal of International Economics.

Agenor, P., J. McDermott, and E. Prasad, (2000) "Macroeconomic Fluctuations in Developing countries: Some Stylized Facts," World Bank Economic Review, 14, May, 25186.

Alessie, R., and A. Lusardi, (1997) "Consumption, Saving and Habit formaiton," Economics Letters, 55, 103-108.

Anderson, T., and C. Hsiao, (1982) "Formulation and Estimation of Dynamic Models Using Panel Data," Journal of Econometrics, Vol. 18, 47-82.

Arellano, M., and S. Bond, (1991) "Some Tests of Specification for Panel Data: Monte Carlo Evidence and an Application to Employment Equations," Review of Economic Studies, Vol. 58, April, 277-97.

Arellano, M., and O. Bover, (1995) "Another Look at the Instrumental Variable Estimation of Error-Component Models," Journal of Econometrics, Vol. 68, 29-51.

Barro, R., and X. Sala-i-Martin, (1995) Economic Growth, New York: McGraw Hill.

Baxter, M. and M. Kouparitsas, (2000) "What Can Account for Fluctuations in the Terms of Trade?", December 2000. NBER Working Paper.

Bevan, D., P. Collier, and J. Gunning, (1993) "Trade Shocks in Developing Countries: Consequences and Policy Responses," European Economic Review, 37, April, 557.65.

Blanchard, O., and S. Fischer, (1989) Lectures on Macroeconomics, Cambridge, MA: MIT Press.

Blundell, R., and S. Bond, (1998) 'Initial Conditions and Moment Restrictions in Dynamic Panel Data Models," Journal of Econometrics, 87, 115-43.

Borensztein, E. and P. Montiel, (1991) "Savings, Investment and Growth in Eastern Europe," IMF Working Paper No. 91/61, Washington, D.C.

Bosworth, B., (1993) Savings and Investment in an Open Economy, Washington D.C.: Brookings Institution.

Bowsher, C., (2002) "On Testing Overidentifying Restrictions in Dynamic Panel Data Models," Economics Letters, 77, 211-20.

Calderon, C., A. Chong, and N. Loayza, (1999) "Determinants of Current Account Deficits in Developing Countries," Policy Research Working Paper, The World Bank, Washington, DC. 
Calderon, C., A. Chong, and L. Zanforlin, (2001) "Are African Current Account Deficits Different? Stylized Facts, Transitory Shocks, and Decomposition Analysis," IMF Working Paper WP/01/4, Washington DC.

Campos, N. and F. Coricelli, (2002) "Growth in Transition: What We Know, What We Don't, and What We Should," Journal of Economic Literature, Vol. XL(3), September, 793-836.

Campos, N. and Y. Kinoshita, (2002) "Foreign Direct Investment as Technology Transferred: Some Panel Evidence from the Transition Economies," The Manchester School, 70, June, 398-419.

Cashin, P., J. McDermott, and A. Scott, (2002) "Booms and Slumps in World Commodity Prices," Journal of Development Economics, 69, 277-96.

Cashin, P., and J. McDermott, (2002) "Terms of Trade Shocks and the Current Account: Evidence from Five Industrial Countries," Open Economies Review, Vol. 13, 219-35.

Chowdhury, A., (1993) "Does Exchange Rate Volatility Depress Trade Flows? Evidence from Error-Correction Models," The Review of Economics and Statistics, 75, November, 7006.

Chowdhury, A., (2001a) "The Impact of Financial Reform on Private Savings in Bangladesh," World Institute for Development Economics Research, Discussion Paper No. 2001/78, Helsinki.

Chowdhury, A., (2001b) "External Debt and Growth in Developing Countries," World Institute for Development Economics Research, Discussion Paper No. 2001/95, Helsinki.

Collins, S., (1991) "Saving Behavior in Ten Developing Countries," in D. Bernheim and J. Shoven (eds.) National Saving and Economic Performance, Chicago: University of Chicago Press.

Conway, P., (2001) Crisis, Stabilization, and Growth: Economic Adjustment in Transition Economies, Boston, MA: Kluwer Academic.

Conway, P., (1995) "Saving in Transition Economies," Policy Research Working Paper No. 1509, The World Bank, Washington, D.C.

Corden, W., (1984) "Booming Sector and Dutch Disease Economics: Survey and consolidation," Oxford Economic Papers, 36, 359-80.

Dayal-Gulati, A., and C. Thimann, (1997) "Saving in Southeast Asian and Latin America Compared: Searching for Policy Lessons," IMF Working Paper WP/97/110.

Deaton, A., and G. Laroque, (1992) "On the Behavior of Commodity Prices," Review of Economic Studies, 59, January, 1-23.

Denizer, C. and H. Wolf, (2000) "The Saving Collapse During the Transition in Eastern Europe," The World Bank Economic Review, 14(3), September, 445-55. 
Denizer, C., H. Wolf, and Y. Ying, (2002) "Household Savings in the Transition," Journal of Comparative Economics, 30, September, 463-75.

Dornbusch, R., (1983) "Real Interest Rates, Home Goods, and Optimal External Borrowing,"Journal of Political Economy, Vol. 91, 141-53.

Edison, H., R. Levine, L. Ricci, and T. Slok, (2002) "International Financial Integration and Economic Growth,” Journal of International Money and Finance, 21, 749-76.

Edwards, S., (1989) "Temporary Terms of Trade Disturbances, the Real Exchange Rate and the Current Account," Economica, 56, 343-57.

Elbadawi, I., and F. Mwega, (1999) "Can Africa's Saving Collapse be Reverted?" in K. Schmidt-Hebbel and L. Sereven (eds.) The Economics of Saving and Growth, Cambridge: Cambridge University Press.

European Bank for Reconstruction and Development, (1996) Transition Report 1996: Infrastructure and Savings, Chapters 6 and 7, London.

Fajnzylber, P., D. Lederman and N. Loayza, (2002) "What Causes Violent Crime?" European Economic Review, 46(7), July, 1323-57.

Fischer, S., (1993) "The Role of Macroeconomic Factors in Growth," Journal of Monetary Economics, 32, 485-512.

Hansen, L., (1982) 'Large Sample Properties of Generalized Methods of Moments Estimators," Econometrica, 50, 1029-54.

Harberger, A., (1950) "Currency Depreciation, Income and the Balance of Trade," Journal of Political Economy, Vol. 53, February, 47-60.

International Monetary Fund, (2000a) Republic of Poland: Selected Issues, Staff Country Report No. 00/60, May, Washington D.C.

International Monetary Fund, (2000b) World Economic Outlook: Focus on Transition Economies, October, Washington, D.C.

Ivaschenko, O., (2002) "Growth and Inequality: Evidence from Transitional Economies," CESIfo Working Paper No. 746, June.

Jappelli, T., and M. Pagano, (1995) "Savings, Growth, and Liquidity Constraints," Quarterly Journal of Economics, 109, 83-109.

Kent, C., (1997) "The Response of the Current Account to Terms of Trade Shocks: A Panel Data Study", Reserve Bank of Australia, Research Discussion Paper 9705.

King, R., and S. Rebelo, (1993) "Low Frequency Filtering and Real Business Cycles," Journal of Economic Dynamics and Control, 17, January, 207-31.

Koivu, T., (2002) ’Does Financial Sector Development Affect Economic Growth in 
Transition Economies?" mimeo, Institute for Transition Economies, Bank of Finland, Helsinki.

Konings, J., M. Rizov, and H. Vandenbussche, (2002) "Investment and Credit Constraints in Transition Economies: Micro Evidence from Poland, the Czech Republic, Bulgaria, and Romania," LICOS Center for Transition Economies, Discussion Paper 112/2002, Belgium.

Kraay, A., (2000) "Household Saving in China," World Bank Economic Review, 14(3), September, 545-70.

Lahiri, A., (1989) 'Dynamics of Asian Savings: The Role of Growth and Age Structure," IMF Staff Papers, 36, 228-61.

Laursen, S., and L. Metzler, (1950) "Flexible Exchange Rates and the Theory of Employment," Review of Economics and Statistics, Vol. 32, November, 281-99.

Leamer, E. (1983) "Let's Take the Con Out of Econometrics," American Economic Review, 73, 31-43.

Levine, R. and D. Renelt, (1992) "A Sensitivity Analysis of Cross Country Growth Regressions," American Economic Review, 82, 942-63.

Loayza, N., K. Schmidt-Hebbel, and L. Serven, (2000) "What Drives Private Saving Across the World?" The Review of Economics and Statistics, Vol. 82, No. 2, 165-81.

Masson, P., T. Bayoumi, and H. Samiei, (1998) 'International Evidence on the Determinants of Private Savings," The World Bank Economic Review, 12, 483-501.

Mendoza, E., (1997) "Terms of Trade Uncertainty and Economic Growth," Journal of Development Economics, 54, 323-56.

Obstfeld, M., (1982) "Aggregate Spending and the Terms of Trade: Is there a LaursenMetlzer Effect?" Quarterly Journal of Economics Vol. 47, May, 251-70.

Ogaki, M., J. Ostry, and C. Reinhart, (1996) "Saving Behavior in Low- and Middle-Income Developing Countries: A Comparison," IMF Staff Papers, Vol. 43, March, 38-71.

Ostry, J., and C. Reinhart, (1992) "Private Saving and Terms of Trade Shocks," IMF Staff Papers, Vol. 39, September, 495-517.

Otto, G., (2003) "Terms of Trade Shocks and the Balance of Trade: There is a HarbergerLaursen-Metzler Effect," Forthcoming, Journal of International Money and Finance.

Radulescu, R. and D. Barlow, (2002) "The Relationship Between Policies and Growth in Transition Countries," Economics of Transition, 10(3), 719-46.

Reinhart, C., and P. Wickham, (1994) "Commodity Prices: Cyclical Weakness or Secular Decline?” IMF Staff Papers, 41, February, 175-213. 
Sachs, J., (1981) "The Current Account and Macroeconomic Adjustments in the 1970s," Brookings Papers on Economic Activity, 1, 201-68.

Schrooten, M. and S. Stephan, (2002) 'Back on Track? Savings Puzzles in EU-Accession Countries," German Institute for Economic Research Discussion Paper No. 306, October.

Spatafora, N. and A. Warner, (1999) "Macroeconomic and Sectoral Effects of Terms of Trade Shocks: The Experience of the Oil-Exporting Developing Countries," IMF Working Paper WP/99/134, October.

Svensson, L., and A. Razin, (1983) "The Terms of Trade and Current Account: The Harberger-Laursen-Metlzer Effect," Journal of Political Economy, Vol. 91, February, 97-125.

United Nations, (2001) Economic Survey of Europe, Prepared by the Secretariat of the Economic Commission for Europe, Geneva.

United Nations, (2002) Economic Survey of Europe, No. 1, Prepared by the Secretariat of the Economic Commission for Europe, Geneva.

World Bank, (1999) Global Development Finance, Washington, D.C.

World Bank, (2000) Global Economic Prospects and the Developing Countries 2000, The World Bank, Washington, D.C.

Zeldes, S., (1989) "Consumption and Liquidity Constraints: An Empirical Investgation," Journal of Political Economy, 97(2), April, 305-46. 


\section{DAVIDSON INSTITUTE WORKING PAPER SERIES - Most Recent Papers}

The entire Working Paper Series may be downloaded free of charge at: www.wdi.bus.umich.edu

CURRENT AS OF 5/6/03

\begin{tabular}{|c|c|c|}
\hline Publication & Authors & Date \\
\hline $\begin{array}{l}\text { No. 572: Private Savings in Transition Economies: Are There Terms of } \\
\text { Trade Shocks? }\end{array}$ & Abdur R. Chowdhury & May 2003 \\
\hline $\begin{array}{l}\text { No. 571: On the long-run determinants of real exchange rates for } \\
\text { developing countries: Evidence from Africa, Latin America and Asia }\end{array}$ & Imed Drine and Christophe Rault & May 2003 \\
\hline $\begin{array}{l}\text { No. 570: A re-examination of the Purchasing Power Parity using non- } \\
\text { stationary dynamic panel methods: a comparative approach for } \\
\text { developing and developed countries }\end{array}$ & Imed Drine and Christophe Rault & May 2003 \\
\hline $\begin{array}{l}\text { No. 569: How Important is Ownership in a Market with Level Playing } \\
\text { Field? The Indian Banking Sector Revisited }\end{array}$ & $\begin{array}{l}\text { Sumon Kumar Bhaumik and } \\
\text { Ralitza Dimova }\end{array}$ & May 2003 \\
\hline $\begin{array}{l}\text { No. 568: On Types of Trade, Adjustment of Labor and Welfare Gains } \\
\text { During Asymmetric Liberalizations }\end{array}$ & Yener Kandogan & May 2003 \\
\hline $\begin{array}{l}\text { No. 567: Technological Progress Through Trade Liberalization in } \\
\text { Transition Countries }\end{array}$ & Yener Kandogan & May 2003 \\
\hline $\begin{array}{l}\text { No. 566: Intra-industry Trade of Transition Countries: Trends and } \\
\text { Determinants }\end{array}$ & Yener Kandogan & May 2003 \\
\hline $\begin{array}{l}\text { No. 565: Local Protectionism and Regional Specialization: Evidence } \\
\text { from China's Industries }\end{array}$ & $\begin{array}{l}\text { Chong-En Bai, Yingjuan Du, } \\
\text { Zhigang Tao, Sarah Y. Tong }\end{array}$ & May 2003 \\
\hline No. 564: Corporate Governance and Market Valuation in China & $\begin{array}{l}\text { Chong-En Bai, Qiao Liu, Joe Lu, } \\
\text { Frank M. Song, and Junxi Zhang }\end{array}$ & May 2003 \\
\hline $\begin{array}{l}\text { No. 563: Revenue Sharing and Control Rights in Team Production: } \\
\text { Theories and Evidence From Joint Ventures }\end{array}$ & $\begin{array}{l}\text { Chong-En Bai, Zhigang Tao, and } \\
\text { Changqi Wu }\end{array}$ & May 2003 \\
\hline $\begin{array}{l}\text { No. 562: Financial Dependence, Stock Market Liberalizations and } \\
\text { Growth }\end{array}$ & Nandini Gupta and Kathy Yuan & May 2003 \\
\hline $\begin{array}{l}\text { No. 561: Growth and Regional Inequality in China During the Reform } \\
\text { Era }\end{array}$ & Derek Jones, Cheng Li and Owen & May 2003 \\
\hline $\begin{array}{l}\text { No. 560: Choice of Ownership Structure and Firm Performance: } \\
\text { Evidence from Estonia }\end{array}$ & $\begin{array}{l}\text { Derek Jones, Panu Kalmi, Niels } \\
\text { Mygind }\end{array}$ & May 2003 \\
\hline No. 559: Explaining Postcommunist Economic Performance & Lawrence P. King & May 2003 \\
\hline $\begin{array}{l}\text { No. 558: Tax Structure and the FDI: The Deterrent Effects of } \\
\text { Complexity and Uncertainty }\end{array}$ & $\begin{array}{l}\text { Kelly Edmiston, Shannon Mudd } \\
\text { and Neven Valev }\end{array}$ & Apr. 2003 \\
\hline No. 557: Provincial Protectionism & Konstantin Sonin & Apr. 2003 \\
\hline $\begin{array}{l}\text { No. 556: Nominal and Real Convergence in Estonia: The Balassa- } \\
\text { Samuelson (dis)connection }\end{array}$ & Balázs Égert & Apr. 2003 \\
\hline $\begin{array}{l}\text { No. 555: Banks-Firms Nexus under the Currency Board: Empirical } \\
\text { Evidence from Bulgaria }\end{array}$ & $\begin{array}{l}\text { Nikolay Nenovsky, Evgeni Peev } \\
\text { and Todor Yalamov }\end{array}$ & Apr. 2003 \\
\hline $\begin{array}{l}\text { No. 554: To Steal or Not to Steal: Firm Attributes, Legal Environment, } \\
\text { and Valuation }\end{array}$ & Art Durnev and E. Han Kim & Apr. 2003 \\
\hline No. 553: Corporate Stability and Economic Growth & $\begin{array}{l}\text { Kathy S. He, Randall Morck and } \\
\text { Bernard Yeung }\end{array}$ & Apr. 2003 \\
\hline $\begin{array}{l}\text { No. 552: So Many Rocket Scientists, So Few Marketing Clerks: } \\
\text { Occupational Mobility in Times of Rapid Technological Change }\end{array}$ & $\begin{array}{l}\text { Nauro F. Campos and Aurelijus } \\
\text { Dabušinskas }\end{array}$ & Mar. 2003 \\
\hline $\begin{array}{l}\text { No. 551: Determinants of Interregional Mobility in Russia: Evidence } \\
\text { from Panel Data }\end{array}$ & $\begin{array}{l}\text { Yuri Andrienko and Sergei } \\
\text { Guriev }\end{array}$ & Feb. 2003 \\
\hline $\begin{array}{l}\text { No. 550: Gross Job Flows in Ukraine: Size, Ownership and Trade } \\
\text { Effects }\end{array}$ & $\begin{array}{l}\text { Jozef Konings, Olga Kupets and } \\
\text { Hartmut Lehmann }\end{array}$ & Mar. 2003 \\
\hline $\begin{array}{l}\text { No. 549: Technology Transfer through FDI in Top-10 Transition } \\
\text { Countries: How Important are Direct Effects, Horizontal and Vertical } \\
\text { Spillovers? }\end{array}$ & $\begin{array}{l}\text { Jože P. Damijan, Mark Knell, } \\
\text { Boris Majcen and Matija Rojec }\end{array}$ & Feb. 2003 \\
\hline $\begin{array}{l}\text { No. 548: Does Foreign Direct Investment Increase the Productivity of } \\
\text { Domestic Firms? In Search of Spillovers through Backward Linkages }\end{array}$ & Beata K. Smarzynska & Mar. 2003 \\
\hline $\begin{array}{l}\text { No. 547: Re-employment Probabilities and Wage Offer Function for } \\
\text { Russian Labor Market }\end{array}$ & Natalia V. Smirnova & Feb. 2003 \\
\hline
\end{tabular}

